\title{
The neurotoxic effects of vitamin $A$ and retinoids
}

\author{
MARCOS ROBERTO DE OLIVEIRA \\ Departamento de Química, ICET, Universidade Federal de Mato Grosso (UFMT), \\ Av. Fernando Corrêa da Costa, 2367, 78060-900 Cuiabá, MT, Brasil \\ Manuscript received on December 10, 2014; accepted for publication on March 4, 2015
}

\begin{abstract}
Vitamin A (retinol) and its congeners - the retinoids - participate in a panoply of biological events, as for instance cell differentiation, proliferation, survival, and death, necessary to maintain tissue homeostasis. Furthermore, such molecules may be applied as therapeutic agents in the case of some diseases, including dermatological disturbances, immunodeficiency, and cancer (mainly leukemia). In spite of this, there is a growing body of evidences showing that vitamin A doses exceeding the nutritional requirements may lead to negative consequences, including bioenergetics state dysfunction, redox impairment, altered cellular signaling, and cell death or proliferation, depending on the cell type. Neurotoxicity has long been demonstrated as a possible side effect of inadvertent consumption, or even under medical recommendation of vitamin A and retinoids at moderate to high doses. However, the exact mechanism by which such molecules exert a neurotoxic role is not clear yet. In this review, recent data are discussed regarding the molecular findings associated with the vitamin A-related neurotoxicity.
\end{abstract}

Key words: mitochondrial dysfunction, neurotoxicity, oxidative stress, retinoids, vitamin A.

\section{INTRODUCTION}

Increased access to vitamin A through fortified foods and supplements is an important strategy to avoid deficiency of such fat-soluble vitamin to humans. However, it is necessary to monitor the impact of such practice on human health due to the potential risk of several deleterious effects classically induced by vitamin A, retinoids, and carotenoids, which are vitamin A precursors from vegetal diet (Snodgrass 1992, Napoli 1999, 2012, Myhre et al. 2003). In addition to its origin from diet, vitamin A is utilized therapeutically in cases of dermatological disturbances, immunodeficiency, weight gain of preterm infants, and leukemia

E-mail: mrobioq@gmail.com
(Tsunati et al. 1990, Ross 2002). It was previously reported that vitamin A doses ranging from 150,000 to $300,000 \mathrm{IU} / \mathrm{kg}$. day ${ }^{-1}$ or more were being utilized in the treatment of leukemic children of different ages (Fenaux et al. 2001). Also, vitamin A at doses that exceed $8500 \mathrm{IU} / \mathrm{kg}$.day ${ }^{-1}$ were administered to very-low-weight-preterm infants during weight gain therapy (Mactier and Weaver 2005). It was previously reported the utilization of vitamin A supplementation at 100,000 to 200,000 IU to treat children in attempt to prevent mortality in GuineaBissau (Fisker et al. 2014). Then, vitamin A may be obtained from both diet and as a supplementation with clinical use or even inadvertently. 
Some authors discuss that it is rare to observe toxicity resulting from excessive vitamin A intake (Allen and Haskell 2002). However, the most common parameters that are analyzed in cases of vitamin A intoxication include observation of acute signs and symptoms, among which are nausea, vomiting, diarrhea, headache, bulging of the fontanelle in infants (as a result of increased intracranial pressure), and fever, to cite a few (Allen and Haskell 2002, Lam et al. 2006). Disturbances related to nervous functions also appear on the list of side effects resulting from excessive vitamin A intake, as for instance confusion, irritability, anxiety, depression, and suicide ideation (Snodgrass 1992). However, such central effects are more commonly observed after chronic vitamin A exposition. On the other hand, acute behavioral impairment was reported in individuals that experienced high vitamin A concentrations due to consumption of bear liver. Such altered behavior was called "polar hysteria" and was compared to schizophrenia (Rodahl and Moore 1943, Restak 1972). Additionally, acute vitamin A intoxication may lead to blurred vision and decreased muscular coordination (Olson 1993).

Some aspects of vitamin A intoxication may be easily assessed, as for example, through analyses of liver and renal function (Penniston and Tanumihardjo 2006). However, with the exception of morphological observations or the consequent behavior resulting from pain (as occurs during headache), it is very difficult to affirm that the acute vitamin A exposition will not lead to sequels that may negatively affect the neuronal function later. Gender, age, and nutritional quality, among other factors, influence the degree of intoxication of almost all existing toxicants (or xenobiotics). Therefore, caution must be taken when concluding that previous vitamin A intake at higher than normal concentrations not induce posterior dysfunction mainly when analyzing neuronal environment, since neurons did not divide during adulthood (with exception to some hippocampal areas and other regions) and its loss would lead to irreversible alterations of brain function (Aimone et al. 2014).

In this review, the effects of vitamin $\mathrm{A}$ on neuronal cells will be described and discussed to show that vitamin $\mathrm{A}$ - and its derivatives, the retinoids - may exert long-term effects on brain areas that either facilitate (indirect effect) or induce (direct effect) central malfunction.

\section{VITAMIN A AND RETINOIDS: A BRIEF OVERVIEW}

Vitamin A (retinol - a hydrocarbon chaincontaining isoprenoid with a hydroxyl group at one end of the molecule) may be obtained from both vegetal (provitamin A) and animal (preformed) diet (Olson 1993, Napoli 1999, 2012). $\beta$-carotene is a main source of vitamin A in vegetables, and retinol esters occurs in animals (Castenmiller and West 1998, von Lintig 2012, Van Loo-Bouwman et al. 2014). After digestion, retinol and retinoids must bind to proteins to be soluble in aqueous solutions such as blood and cytosol (Noy 2000, Napoli 2012). The cellular metabolism of retinol is as follows: retinol is converted to retinal (an aldehyde) or to retinoic acid (a carboxylic acid) through oxidation of the hydroxyl group (Olson 1993). Furthermore, retinol may be esterified by lecithin retinol acyl transferase (LRAT) or acyl-Coa acyl transferase (ARAT) leading to the formation of palmitate retinol, as well as other chemical forms, as for instance retinol oleate, retinol linoleate, and more (Sauvant et al. 2003). Retinoic acids (mainly alltrans-retinoic acid and 9-cis-retinoic acid) exert its effects by binding to receptors that act as nuclear factors when translocate to nucleus (Napoli 1996). However, an increasing body of evidence shows that retinol and retinoids may trigger specific signals through non-genomic events (Piskunov et al. 2014, Rochette-Egly 2015).

Vitamin A plays important roles during both mammalian development and adulthood through maintenance of several tissue functions, including the central nervous system as a whole (Olson 1993, Tanumihardjo 2004, Tafti and Ghyselinck 2007). 
This vitamin and its derivatives participate in the regulation of cell proliferation, differentiation, survival, and death (by triggering apoptosis), leading to the formation of the normal shape of the embryo, organogenesis, and tissue physiology, for example (Das et al. 2014). Furthermore, some biological processes including, for example, vision, structure and function of skin and bones, immune defenses, and neuronal activity will depend on regular access to vitamin A during the entire human life (Olson 1993, Napoli 1996, Huang et al. 2014).

The main site of vitamin A storage in mammals is the liver, but it is also possible to find vitamin esters in adipose tissue (Napoli 1996, Van LooBouwman et al. 2014). Vitamin A content in the liver of adult humans is about $100 \mu \mathrm{g} / \mathrm{g}$ (Furr et al. 1989). It was suggested that a concentration of vitamin A of roughly $300 \mu \mathrm{g} / \mathrm{g}$ in the liver reveals intoxication (Olson 1993).

\section{THE BIOLOGY OF VITAMIN A IN THE CENTRAL NERVOUS SYSTEM}

After hydrolysis of retinol esters, retinol binds to retinol binding proteins (RBP) and is transported through circulation. In the target organ, a membrane receptor with high affinity for retinol mediates its uptake (Kawaguchi et al. 2007). All-trans-retinoic acid is produced from retinol by retinol dehydrogenase (generating retinal) and retinaldehyde dehydrogenase (producing retinoic acid) (Napoli 1996). The synthesis of alltrans-retinoic acid occurs in several brain areas of mammals, including cerebrum, cerebellum, meninges, basal ganglia, and hippocampus (Lane and Bailey 2005). Interestingly, it was demonstrated that retinal dehydrogenase enzyme expression occurs in blood vessels of all brain areas (Thompson Haskell et al. 2002). Recently, it was published that astrocytes may participate in the maintenance of the homeostasis of retinoids levels in brain by regulating its synthesis (Shearer et al. 2012a). Moreover, retinoid binding proteins were detected throughout the entire brain (Lane and Bailey 2005). Cellular retinol binding proteins (CRBP-I and II) and cellular retinoic acid binding proteins (CRABP-I and II) solubilize retinoids in the cytoplasm and avoid non-specific interactions and even oxidation of such molecules (Napoli 1996, 1999, 2012, Folli et al. 2001). The binding of retinoic acids to cellular retinoic acid binding protein (CRABP) forms a complex that it is thought to migrates to the nucleus and induce different effects through interacting with nuclear receptors to retinoic acid (RAR and RXR) (Lane and Bailey 2005, Shearer et al. 2012b). Brain contains RAR and RXR and its functions are better observed during development. During adulthood, these nuclear receptors are still found in neuronal cells, but show a specific pattern of localization (Tafti and Ghyselinck 2007). It was reported that RAR binds with all-trans-retinoic acid and with 9-cisretinoic acid (with lower affinity for the later) and RXR binds with 9-cis-retinoic acid (Napoli 1996, Lane and Bailey 2005). There is a myriad of genes that contain response elements to retinoids in adult mammalian brain, as previously reviewed (Lane and Bailey 2005). Then, retinoids are metabolized in brain areas and exert its effects in nervous and glial cells specifically throughout all life.

However, even being a biological target of vitamin $A$ and its derivatives, the ability of vitamin A to induce serious effects that may compromise neuronal function has been described. Such effects include impaired bioenergetic parameters related to mitochondrial function, oxidative and nitrosative stress, alterations of dopamine signaling, and behavioral disturbances, to cite some examples.

\section{MOLECULAR EVIDENCES OF VITAMIN A-RELATED NEUROTOXICITY}

Even though vitamin $\mathrm{A}$ and its derivatives are essential during both development and maintenance of central nervous system activity, there is a considerable body of evidences showing that vitamin A concentrations exceeding that which is required for normal function of cells lead 
to deleterious effects including disruption of the redox environment, mitochondrial dysfunction, and induction of cell death, as discussed below (Napoli 1999, Myhre et al. 2003, Lane and Bailey 2005).

All-trans-retinoic acid, a retinoid originated from retinol, is able to induce oxidative stress in cultured Sertoli cells (Conte da Frota et al. 2006), but not in PC12 cell line (Gelain and Moreira 2008), which is derived from pheochromocytoma of rat adrenal medulla (which is, in turn, originated from the neural crest) and produces dopamine and norepinephrine. In PC12 cell line treated with retinol, increased rates of reactive oxygen species production through a real-time 2',7'-dichlorohydrofluorescein diacetate (DCFHDA) assay designed for live cells were observed (Wang and Joseph 1999). Also, decreased viability was reported in PC12 cells treated with retinol. DCFH-DA serves as a probe to detection of hydrogen peroxide, hydroxyl, and peroxyl radicals (LeBel et al. 1992). Then, retinol, but not alltrans retinoic acid may alter redox environment of such catecholamine producing cells, possibly leading to loss of viability by a mechanism that may be associated to its ability to act as a prooxidant. However, it remains to be determined whether the loss of cell viability is really related to the pro-oxidant effect of retinol in that cell system. Recently, it was demonstrated that all-trans retinoic acid modulates gene expression through a redox mechanism during SH-SY5Y cell line differentiation, since the effects seen were blocked by an antioxidant that is analogue to $\alpha$-tocopherol (de Bittencourt Pasquali et al. in press). However, it was not analyzed in that work whether retinoic acid altered redox environment parameters, as for instance by inducting oxidative damage or increasing the rates of reactive species.

Vitamin A is necessary for both development and maintenance of the nigrostriatal axis (substantia nigra and striatum), which regulates dopamine signaling in brain. However, as mentioned above, such vitamin and its derivatives may cause oxidative impairment of such brain areas by increasing reactive oxidative species. Actually, it was reported that vitamin A supplementation (in the form of retinol palmitate) at doses commonly utilized clinically $\left(1,000\right.$ to $9,000 \mathrm{IU} / \mathrm{kg}$ day $^{-1}$ for 3 , 7 , or 28 days) induced some redox disturbances in the nigrostriatal axis of adult male rats. Increased lipid peroxidation, protein carbonylation, and oxidation of protein thiol groups were observed in the substantia nigra and striatum of vitamin A-treated rats (De Oliveira et al. 2007a, 2008). Moreover, vitamin A modulated antioxidant enzyme activity, as observed with superoxide dismutase (SOD) and, in some cases, with catalase (CAT), but not with glutathione peroxidase (GPx). It is interesting to note that, in that experimental model, retinol palmitate supplementation induced an increase in SOD enzyme activity, but did not affect either CAT or GPx enzyme activity or even decreased CAT enzyme activity. Therefore, vitamin A is favoring an increase in $\mathrm{H}_{2} \mathrm{O}_{2}$ production that may lead to hydroxyl radical $(\mathrm{OH})$ formation through Fenton reaction (Halliwell 2006), since SOD converts $\mathrm{O}_{2}^{-\bullet}$ to $\mathrm{H}_{2} \mathrm{O}_{2}$, but this reactive specie probably accumulates due to decreased or unaltered CAT and unaltered GPx enzyme activities. Regarding the toxic effects of $\mathrm{O}_{2}^{-\bullet}$, it was shown that $\mathrm{O}_{2}^{-\bullet}$ is able to inhibit CAT enzyme activity directly (Kono and Fridovich 1982). Thus, it may be a mechanism by which vitamin A modulates CAT enzyme activity in vivo. Interestingly, vitamin A supplementation for 28 days decreased rat exploration of and locomotion in an open field arena (De Oliveira et al. 2007a, 2008). However, it was not analyzed whether such behavioral abnormalities were associated with impaired redox status observed in the brain areas that participate in movement control.

More recently, De Oliveira et al. (2012a) demonstrated that vitamin A supplementation at 500 to $2,500 \mathrm{IU} / \mathrm{kg}$. day ${ }^{-1}$ induced mitochondrial dysfunction and increased $\beta$-amyloid ${ }_{1-40}$ peptide and tumor necrosis factor-alpha (TNF- $\alpha$ ) contents in substantia nigra and striatum of adult rats. Additionally, increased monoamine oxidase (MAO) enzyme activity was observed in that 
experimental model. Mitochondrial dysfunction was found by assessing mitochondrial electron transfer chain activity. Decreased complex I-III, complex II, succinate dehydrogenase (SDH), complex II-III, and complex IV enzyme activity was reported, which may lead not only to decreased rates of ATP production, but may favor electron leakage from that system, which may lead to $\mathrm{O}_{2}^{-\bullet}$ formation (Halliwell 2006). In addition, it was seen increased Mn-SOD (manganese SOD - the mitochondrial SOD) enzyme activity, as well as MAO enzyme activity was observed increased. These two enzymes differ in location (Mn-SOD is a mitochondrial matrix enzyme, and MAO is located at the outer mitochondrial membrane), but both produce $\mathrm{H}_{2} \mathrm{O}_{2}$ during the reaction of dismutation of $\mathrm{O}_{2}^{-\bullet}$ and degradation of dopamine, respectively (Halliwell 2006, Edmondson 2014). Then, mitochondria seem to be a potential source of $\mathrm{H}_{2} \mathrm{O}_{2}$ in the case of increased vitamin A intake as a supplement. Interestingly, vitamin A supplementation also induced a decrease in the immunocontent of D2 receptor (D2R) in both substantia nigra and striatum (De Oliveira et al. 2012a). Low levels of D2R may cause an increase of dopamine release from catecholaminergic neurons, which may lead to exceeding dopamine levels in both extracellular and intracellular environments of post-synaptic neurons (Lotharius and Brundin 2002, Jorg et al. 2014). Dopamine is very reactive under physiologic $\mathrm{pH}$, giving rise to semi-quinones that may react with thiol groups in protein and affect its structure and function (Graham 1978, Maker et al. 1981, Lotharius and Brundin 2002). In fact, increased concentration of oxidized protein thiol groups was observed in that experimental model. However, it remains to be investigated whether a causative link between such effects really exists. Carta et al. (2006) demonstrated that vitamin A deficiency impaired locomotion and striatal cholinergic function in rats. Even though vitamin A is necessary to modulate signaling pathways associated to dopamine and other neurotransmitters (Lane and Bailey 2005), excessive vitamin A intake may trigger several neuronal dysfunctions that may be originated from its pro-oxidant ability, for example.

It is interesting the fact that vitamin A supplementation also increased glutathione-S transferase (GST) enzyme activity in several rat brain areas (De Oliveira et al. 2009f, 2011a, 2012a, c). GST conjugates reduced glutathione (GSH) with apolar xenobiotics in order to increase its solubility in aqueous solution, rendering its excretion easy after biotransformation (Sheehan et al. 2001). However, by increasing GST enzyme activity during vitamin A metabolism, such enzyme consumes greater amounts of GSH. GSH is the major non-enzymatic antioxidant inside cells and organelles such as mitochondria (Halliwell 2006). Thereby, vitamin A affects neuronal redox status not by directly inducing the production of $\mathrm{O}_{2}^{-\bullet}$, for example, but also through increasing the consumption and consequent excretion of GSH, weakening the antioxidant power of cells.

Sub acute vitamin A supplementation also increased both 3-nitrotyrosine (total and mitochondrial) and $\alpha$-synuclein contents in the rat substantia nigra and striatum (De Oliveira et al. 2012a). Increased 3-nitrotyrosine levels may result from high rates of $\mathrm{O}_{2}^{-\bullet}$ and $\mathrm{NO}^{1}$ production (Squadrito and Pryor 1998, Radi 2013). Indeed, it was demonstrated that vitamin A intake increased mitochondrial $\mathrm{O}_{2}^{-\bullet}$ production in different rat tissues including brain (De Oliveira and Moreira 2007, 2008, De Oliveira et al. 2009a, b, c, d, e, f, 2011a, $2012 b$ ). The protein $\alpha$-synuclein may be a target of 3-nitrotyrosine, as previously demonstrated (Giasson et al. 2000, Souza et al. 2000). Aggregated $\alpha$-synuclein may lead to proteasome inhibition, a step towards accumulation of protein aggregates inside cells (Snyder et al. 2003). Nagl et al. (2009) published the mechanismby which all-trans-retinoic acid induced the expression of neuronal nitric oxide synthase (nNOS) in TGW-nu-I, a neuroblastoma cell line. They found that all-trans-retinoic acid induced nNOS expression through activation of the phosphatidylinositol 3-kinase (PI3K)/Akt 
signaling pathway and the orphan nuclear receptor DAX1 (NR0B1). All-trans-retinoic acid, among other retinoids, as for example, 9-cis-retinoic acid, are originated from vitamin A intake in vivo (Napoli 1996, 1999, 2012), and increased access to retinoids may lead to an increased expression of nNOS and augmented rates of NO production, which favors increased production of peroxynitrite $\left(\mathrm{ONOO}^{-}\right)$, a reactive specie that give rise to nitryl cation $\left(\mathrm{NO}_{2}^{+}\right)$, nitrogen diozide radical $\left({ }^{\bullet} \mathrm{NO}_{2}\right)$, and hydroxyl radical $\left({ }^{\bullet} \mathrm{OH}\right)$ through a reaction called homolytic fission (Radi 2013, Carballal et al. 2014). In spite of this evidences, the effects of vitamin A supplementation on NOS enzyme activity and expression in the mammalian brain remain to be investigated.

Even though NO may play an important role in the neurotoxicity elicited by vitamin A, the cotreatment with NG-nitro-L-arginine methyl ester (L-NAME) did not affect either mitochondrial dysfunction or other redox-related parameters in the experimental model of vitamin A supplementation at clinical doses $\left(1,000-9,000 \mathrm{IU} / \mathrm{kg}\right.$. day ${ }^{-1}$ for 28 days) (De Oliveira et al. 2012c). Furthermore, L-NAME co-treatment did not prevent behavioral disturbances induced by vitamin A. Taken together, these data suggest that the neurotoxicity of vitamin $\mathrm{A}$ is not dependent on the formation of $\mathrm{NO}^{1}$, $\mathrm{ONOO}^{-}$, and/or 3-nitrotyrosine. However, the experimental model utilized has some limitations, since only one dose of L-NAME was tested. For a better conclusion, two or even three concentrations of L-NAME should be applied.

In cerebral cortex and cerebellum, retinol palmitate supplementation at clinical doses $(1,000$ to $9,000 \mathrm{IU} / \mathrm{kg}$. day ${ }^{-1}$ ) for 3,7 , or 28 days induced oxidative stress and mitochondrial dysfunction, as assessed through quantification of lipid peroxidation, protein carbonylation, and oxidation of protein thiol groups (De Oliveira and Moreira 2007). Similar results were obtained in vitro by exposing isolated rat liver mitochondria to retinol. It was observed that $20-40 \mu \mathrm{M}$ retinol increased $\mathrm{O}_{2}^{-\bullet}$ production and lipid peroxidation levels
(Klamt et al. 2005). It has been reported that higher than normal mitochondrial lipid peroxidation levels may lead to cytochrome c release through oxidation of cardiolipin (Hüttemann et al. 2011). In the cytoplasm, cytochrome $\mathrm{c}$ may trigger apoptosis (Green et al. 2014). However, release of cytochrome c from mitochondria is associated with increased rates of $\mathrm{O}_{2}^{-\bullet}$ production due to electron leakage from the mitochondrial electron transfer chain (Halliwell 2006, Hüttemann et al. 2011). Then, $\mathrm{O}_{2}^{-\bullet}$ is able to increase its own production by favoring cytochrome $\mathrm{c}$ release through cardiolipin oxidation. Vitamin A (retinol) alters mitochondrial function and may induce cell death by a mitochondrial dependent route, as demonstrated (Klamt et al. 2008). Vitamin A supplementation did not induce cell death in any rat brain region investigated, but increased caspase- 3 enzyme activity was found in the rat cerebral cortex after sub acute treatment the vitamin (De Oliveira et al. 2010). However, it was not analyzed whether such enzyme activation participates in the mechanism of cell death in such rat brain region. It is known that 13-cis-retinoic acid may suppress cell survival in the hippocampus of mice (Sakai et al. 2004). Additionally, cell division may be inhibited in vivo by the same retinoid (Crandall et al. 2004). Indeed, such cellular impairments may be the cause of depressive behavior previously reported in mice exposed to 13-cis-retinoic acid (O'Reilly et al. 2006), as well as explain, at least in part, the decreased capacity in animals to learn after receiving such drug (Crandall et al. 2004). Actually, anxiety-like behavior was observed in adult rats maintained under vitamin A supplementation at pharmacological doses administered sub acutely (De Oliveira et al. 2007b). On the other hand, vitamin A deficiency impaired cognitive functions, as for instance learning and memory in different experimental models (Jiang et al. 2012, Navigatore-Fonzo et al. 2014, Hou et al. 2015).

Vitamin A supplementation also affected the levels of one of the most important neurotrophins in the mammalian brain experimentally. It was 


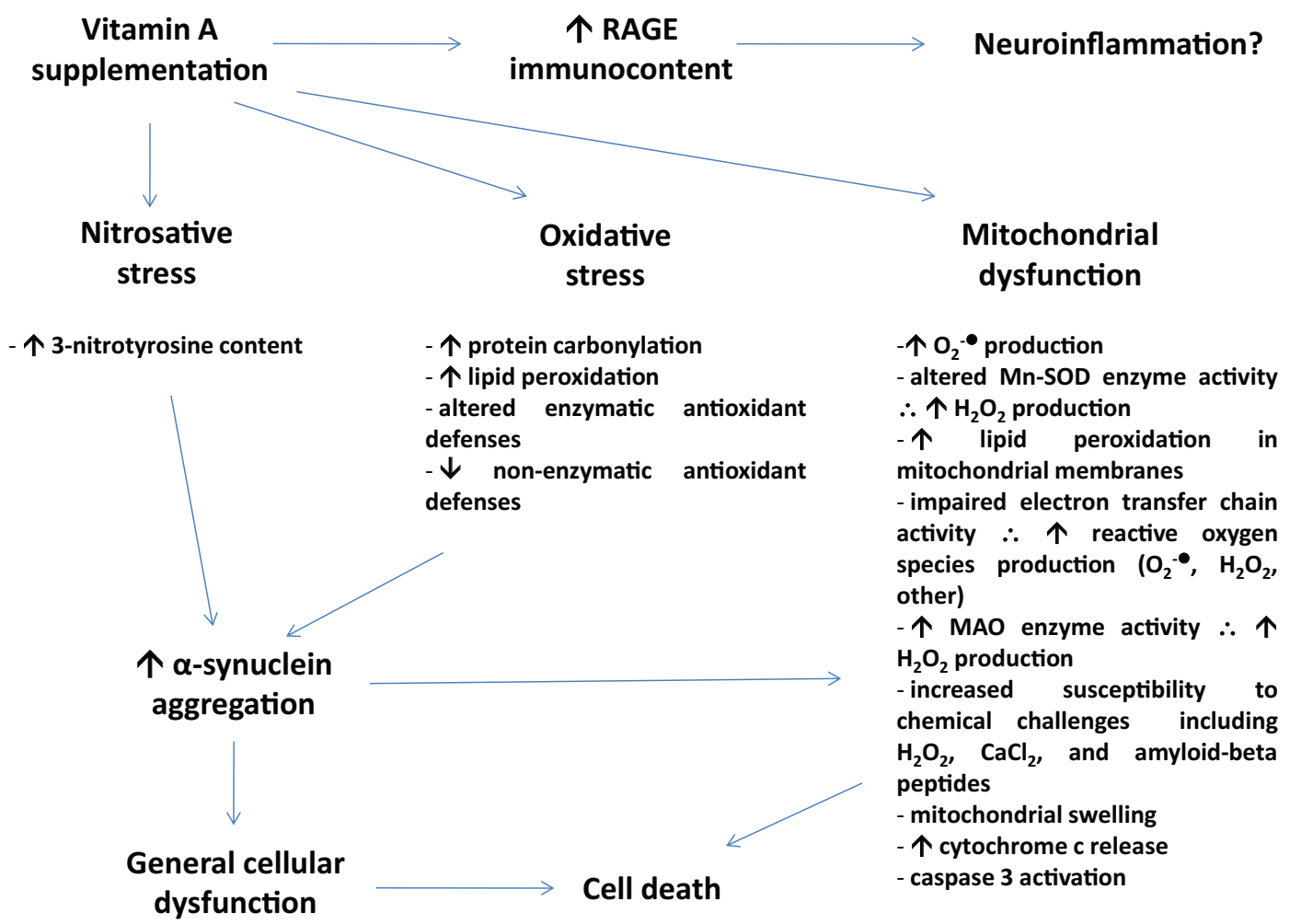

Figure 1 - A summary of possible effects elicited by vitamin A (either retinol or retinol palmitate) on the mammalian central nervous system. It has been demonstrated that vitamin A supplementation (in the form of retinol palmitate or retinol) is able to induce an increase in the immunocontent of RAGE, which mediates neuroinflammation in some experimental models. Additionally, such supplementation may lead to altered redox environment parameters, which has been evidenced as oxidative and nitrosative stress. Moreover, vitamin A supplementation induces mitochondrial dysfunction in vitro and in vivo. Increased levels of $\mathrm{O}_{2}^{-\bullet}$ may affect the function of several enzymes, including catalase (CAT) and Mn-superoxide dismutase (Mn-SOD, the mitochondrial isoform of SOD). Furthermore, $\mathrm{O}_{2}^{\bullet}$ may be a consequence of impaired electron transfer chain due to vitamin A-dependent electron leakage from that complex system. Vitamin A, which is liposoluble, may interact with mitochondrial membranes disrupting the normal flow of electrons between mitochondrial complexes, which in turn may favor abnormal electron flux. Alternatively, increased activity of this system may be due to an augmentation in the need for adenosine triphosphate (ATP) in acute phases of intoxication with vitamin A. Both Mn-SOD and monoamine oxidase (MAO) enzyme activities may lead to increased hydrogen peroxide $\left(\mathrm{H}_{2} \mathrm{O}_{2}\right)$ production, which may diffuse from mitochondria to other organelles. Increased levels of oxidative and nitrosative stress markers may induce $\alpha$-synuclein aggregation, which may interact negatively with mitochondria (please see text for details). General cell dysfunction and cell death may result if vitamin A concentration remains elevated. Other effects may be induced by vitamin A and/or retinoids on neuronal cells. This figure represents just a summary of some of them.

reported that retinol palmitate supplementation $\left(1,000\right.$ to $\left.9,000 \mathrm{IU} / \mathrm{day}^{-1}\right)$ for 28 days decreased brain-derived neurotrophic factor (BDNF) in the rat hippocampus (De Oliveira et al. 2011a). BDNF regulates neuronal plasticity, bioenergetics, mitochondrial biogenesis, and neuronal survival, to cite a few (Cheng et al. 2010, Agrawal et al. 2014,
Marosi and Mattson 2014). Decreased BDNF may lead to limited mitochondrial biogenesis and mitochondrial dysfunction during events of neurotoxicity. By decreasing BDNF levels, vitamin A impairs not only neuronal plasticity that is necessary to the learning and memory processes, but also the ability of this organelle to produce 
adequate amounts of ATP needed to counteract acute and chronic stress. In fact, it was demonstrated that vitamin A affects mitochondrial function in vitro and in vivo, as discussed above.

In another study, it was observed that vitamin A daily administrated to rats is able to increase receptor for advanced glycation endproducts (RAGE) immunocontent in rat cerebral cortex (De Oliveira et al. 2009e). This receptor is implicated in the amplification of oxidative stress by a neuroinflammation-related mechanism (Brownlee 2000, Schmidt et al. 2001, Bierhaus et al. 2005). Moreover, RAGE may play a crucial role in the onset and progression of Alzheimer's disease, as previously postulated (Sato et al. 2006). In fact, RAGE mediates the transport of $\beta$-amyloid peptides from blood to brain across the blood-brain barrier (Deane et al. 2003) and possibly plays a crucial role in the onset of Alzheimer's disease in diabetic patients. Additionally, sustained RAGE activation may trigger cell death and tissue dysfunction (Bierhaus et al. 2005). More investigations are needed to better address the role of vitamin $\mathrm{A}$ on inducing RAGE activation in brain.

It was recently demonstrated that retinol palmitate supplementation at 100,200 , or $500 \mathrm{IU} /$ kg.day ${ }^{-1}$ for 2 months did not induce any antioxidant effect in frontal cortex, hippocampus, striatum, and cerebellum of adult female rats (De Oliveira et al. 2011b). Retinol palmitate at $100 \mathrm{IU} / \mathrm{kg}$ is equivalent to $7000 \mathrm{IU} /$ day for a human weighing $70-\mathrm{kg}$. Such dosage is far below the approximate 25,000 IU/day that some vitamin A supplements users ingest. Additionally, such supplementation did not decrease endoplasmic reticulum stress, as assessed through quantification of BiP/GRP78 protein level. In addition, vitamin A did not affect either TNF- $\alpha$ or RAGE immunocontent, showing that vitamin A may not be the best choice to prevent inflammation in such brain areas.

Interestingly, it was reported that in vivo retinol palmitate supplementation increased in vitro susceptibility of mitochondrial to different challenges. Mitochondria were isolated from substantia nigra, striatum, frontal cortex, and hippocampus and challenged with $\mathrm{H}_{2} \mathrm{O}_{2}, \beta$-amyloid peptide $_{1-40}$, and $\mathrm{CaCl}_{2}$ and it was observed an increased impact of each challenge on mitochondria that were isolated from retinol palmitate-treated rats (De Oliveira et al. 2012a, b). It suggests that prior vitamin A supplementation may increase vulnerability of mitochondria to posterior chemical insult that affect mitochondrial electron transfer chain activity, for example, as demonstrated. Thus, excessive intake of vitamin A may, at least in part, facilitate neuronal abnormalities (including both redox and bioenergetics states) that may appear from other pathological event, as for instance increased rates of $\beta$-amyloid peptides production in the case of Alzheimer disease. However, the data obtained with animal research are not sufficient to conclude that vitamin A supplementation is a risk factor for neurodegenerative diseases in humans. Nonetheless, it has been demonstrated that vitamin A intake among well-nourished subjects may lead to decreased life quality and increased mortality rates (Bjelakovic et al. 2007, 2008, 2012, 2014). Recently, it was suggested that mefloquine (a drug used to prevent and treat malaria) may elicit its deleterious effects by altering the concentrations of retinoids in circulation, leading to cognitive disturbances, as for example, anxiety, depression, psychosis, and violence (Mawson 2013). The author suggests that mefloquine would be able to impair retinoid metabolism in liver, causing posterior spillage of retinoids from liver to blood at toxic concentrations. Takeda et al. (2014) did not find any association between blood levels or dietary intake of retinoids and the risk of Parkinson's disease, i.e. whether decreased levels of retinoids may favor PD is not known, but it did not prevent individuals from such neurodegenerative disease. In spite of this, some authors have reported that vitamin A derivatives may reduce chemotherapyassociated neuropathy in both animal model and patients under lung cancer therapy (Arrietá et al. 2011). Furthermore, retinol and retinoids possess antioxidant ability, since such effects have been 
demonstrated in different experimental models. However, it is mainly an issue of dosage. Depending on retinoid concentration, but also other factors, as for instance age, gender, and some nutritional parameters, as well as exposition to environmental toxicants, retinoids may favor a pro-oxidant state and cell damage with consequent increased rates of cell death and inflammation. Some of the effects discussed here are summarized in Figure 1.

\section{CONCLUSIONS}

Overall, even though vitamin A is an essential micronutrient to normal brain development and function, caution must be taken when administering such vitamin to individuals without any sign of deficiency and/or with history of neurodegenerative diseases in the family, for example, since central nervous system is a clear target of vitamin A-associated toxicity. The utilization of vitamin A or retinoids in the treatment of some types of cancer and dermatological disturbances is based on the fact that such molecules may trigger cell death or slow cell cycle progression, leading to decreased rates of tumor growth. However, it would be catastrophic if an individual with history of neurodegenerative disease in the family exceeds vitamin A intake through either supplement use or clinical administration, for example. More investigations are needed to clarify the mechanisms by which vitamin $\mathrm{A}$ and its derivatives affect neuronal function, as well as the glial network.

\section{ACKNOWLEDGMENTS}

I would like to thank MSc. Fernanda Rafaela Jardim for the help with English grammar revision.

\section{RESUMO}

A vitamina A (retinol) e seus congêneres - os retinoides - participam de um vasto número de eventos biológicos, como por exemplo, diferenciação, proliferação, sobrevivência, e morte da célula necessários para manter a homeostasia tecidual. Além disso, tais moléculas podem ser aplicadas como agentes terapêuticos no caso de algumas doenças, incluindo distúrbios dermatológicos, imunodeficiência, e câncer (principalmente, leucemia). Apesar disto, há um crescente corpo de evidências mostrando que doses de vitamina A que excedem as necessidades nutricionais podem levar a consequências negativas, incluindo disfunção do estado bioenergético, prejuízo redox, sinalização celular alterada, e morte ou proliferação celulares, dependendo do tipo celular. Neurotoxicidade tem sido demonstrada há bastante tempo como um possível efeito colateral do consumo inadvertido ou mesmo sob recomendação médica de vitamina $\mathrm{A}$ e de retinoides em doses moderadas e altas. No entanto, o mecanismo exato pelo qual tais moléculas exercem um papel neurotóxico ainda não é claro. Nesta revisão, dados recentes em relação aos achados moleculares associados com a neurotoxicidade relacionada à vitamina A são discutidos.

Palavras-chave: disfunção mitocondrial, neurotoxicidade, estresse oxidativo, retinoides, vitamina $\mathrm{A}$.

\section{REFERENCES}

Agrawal R, Tyagi E, Vergnes L, Reue K And GomezPINILla F. 2014. Coupling energy homeostasis with a mechanism to support plasticity in brain trauma. Biochim Biophys Acta 1842: 535-546.

Aimone JB, Li Y, Lee SW, Clemenson GD, Deng W AND GAGE FH. 2014. Regulation and function of adult neurogenesis: from genes to cognition. Physiol Rev 94: 991-1026.

Allen LH AND HASKell M. 2002. Estimating the potential for vitamin A toxicity in women and young children. J Nutr 132: 2907S-2919S.

ARRIETA Ó ET AL. 2011. Retinoic acid reduces chemotherapyinduced neuropathy in an animal model and patients with lung cancer. Neurology 77: 987-995.

Bierhaus A, HuMPERT PM, MORCOS M, WENDT T, CHAVAKIS T, ARnold B, Stern DM AND NAWroth PP. 2005. Understanding RAGE, the receptor for advanced glycation end products. J Mol Med (Berl) 83: 876-886.

BJELAKOVIC G, NiKOLOVA D AND GLUUD C. 2014. Antioxidant supplements and mortality. Curr Opin Clin Nutr Metab Care 17: 40-44.

BJelakovic G, Nikolova D, GluUd Ll, Simonetti RG AND GLUUD C. 2007. Mortality in randomized trials of antioxidant supplements for primary and secondary prevention: systematic review and meta-analysis. JAMA 297: 842-857. 
BJElakovic G, Nikolova D, GLuUd LL, SimonetTi RG AND GLUUD C. 2008. Antioxidant supplements for prevention of mortality in healthy participants and patients with various diseases. Cochrane Database Syst Rev 2: CD007176.

BJElakovic G, Nikolova D, GLUUd LL, SimonetTi RG AND GLUUD C. 2012. Antioxidant supplements for prevention of mortality in healthy participants and patients with various diseases. Cochrane Database Syst Rev 3: CD007176.

BROWNLEE M. 2000. Negative consequences of glycation. Metabolism 49: 9-13.

Carballal S, Bartesaghi S And Radi R. 2014. Kinetic and mechanistic considerations to assess the biological fate of peroxynitrite. Biochim Biophys Acta 1840: 768-780.

Carta M, Stancampiano R, Tronci E, Collu M, Usiello A, Morelli M and Fadda F. 2006. Vitamin A deficiency induces motor impairments and striatal cholinergic dysfunction in rats. Neuroscience 139: 1163-1172.

CASTENMILlER JJN AND WeSt CE. 1998. Bioavailability and bioconversion of carotenoids. Annu Rev Nutr 18: 19-38.

Cheng A, Hou Y AND MATTSON MP. 2010. Mitochondria and neuroplasticity. ASN Neuro 2: e00045.

Conte da Frota Jr ML, Gomes da Silva E, Behr GA, Roberto de Oliveira M, DAL-Pizzol F, Klamt F AND MOREIRA JC. 2006. All-trans retinoic acid induces free radical generation and modulate antioxidant enzyme activities in rat Sertoli cells. Mol Cell Biochem 285: 173179.

Crandall J, Sakai Y, Zhang J, Koul O, Mineur Y, Crusio WE AND MCCAFFERY P. 2004. 13-cis-retinoic acid suppresses hippocampal cell division and hippocampaldependent learning in mice. Proc Natl Acad Sci USA 101: 5111-5116.

DAS BC ET AL. 2014. Retinoic acid signaling pathways in development and diseases. Bioorg Med Chem 22: 673-683.

De Bittencourt Pasquali MA, De Ramos VM, Albanus RD, Kunzler A, De Souza LH, Dalmolin RJ, Gelain DP, Ribeiro L, CARro L AND Moreira JC. In press. Gene Expression Profile of NF- $\kappa \mathrm{B}, \mathrm{Nrf2}$, Glycolytic, and p53 Pathways During the SH-SY5Y Neuronal Differentiation Mediated by Retinoic Acid.

De OliveIRA MR, DA Rocha RF AND MOREIRA JC. 2012b. Increased susceptibility of mitochondria isolated from frontal cortex and hippocampus of vitamin A-treated rats to non-aggregated amyloid- $\beta$ peptides $1-40$ and $1-42$. Acta Neuropsychiatr 24: 101-108.

DE OLIVEIRA MR, DA ROCHA RF, PASQUALI MAAND MOREIRA JC. 2012a. The effects of vitamin A supplementation for 3 months on adult rat nigrostriatal axis: increased monoamine oxidase enzyme activity, mitochondrial redox dysfunction, increased $\beta$-amyloid(1-40) peptide and TNF- $\alpha$ contents, and susceptibility of mitochondria to an in vitro $\mathrm{H}_{2} \mathrm{O}_{2}$ challenge. Brain Res Bull 87: 432-444.
DE OlIVEIRA MR, DA ROCHA RF, SCHNORR CEAND MOREIRA JC. 2012c. L-NAME cotreatment did prevent neither mitochondrial impairment nor behavioral abnormalities in adult Wistar rats treated with vitamin A supplementation. Fundam Clin Pharmacol 26: 513-529.

De Oliveira MR, Da Rocha RF, Stertz L, Fries GR, De OliVeIRA DL, KAPCZINSKI F AND MOREIRA JC. 2011a. Total and mitochondrial nitrosative stress, decreased brainderived neurotrophic factor (BDNF) levels and glutamate uptake, and evidence of endoplasmic reticulum stress in the hippocampus of vitamin A-treated rats. Neurochem Res 36: 506-517.

De Oliveira Mr, De Bittencourt Pasquali MA, Silvestrin RB, Mello e Souza T And Moreira JC. 2007a. Vitamin A supplementation induces a prooxidative state in the striatum and impairs locomotory and exploratory activity of adult rats. Brain Res 1169: 112-119.

De OliVeIra MR, LOREnZI R, SCHNORR CE, MORRONEM AND MOREIRA JC. 2011b. Increased 3-nitrotyrosine levels in mitochondrial membranes and impaired respiratory chain activity in brain regions of adult female rats submitted to daily vitamin A supplementation for 2 months. Brain Res Bull 86: 246-253.

De OliVeIRA MR AND MoreIRA JC. 2007. Acute and chronic vitamin A supplementation at therapeutic doses induces oxidative stress in submitochondrial particles isolated from cerebral cortex and cerebellum of adult rats. Toxicol Lett 173: 145-150.

DE OlIVEIRA MR AND MoreIRA JC. 2008. Impaired redox state and respiratory chain enzyme activities in the cerebellum of vitamin A-treated rats. Toxicology 253: 125-130.

De Oliveira Mr, Oliveira MW, Behr GA, De BitTencourt PAsquali MA AND Moreira JC. 2009e. Increased receptor for advanced glycation endproducts immunocontent in the cerebral cortex of vitamin A-treated rats. Neurochem Res 34: 1410-1416.

De Oliveira MR, Oliveira MW, Behr GA, Hoff ML, DA ROCHA RF AND MOREIRA JC. 2009f. Evaluation of the effects of vitamin A supplementation on adult rat substantia nigra and striatum redox and bioenergetic states: mitochondrial impairment, increased 3-nitrotyrosine and alpha-synuclein, but decreased D2 receptor contents. Prog Neuropsychopharmacol Biol Psychiatry 33: 353-362.

De Oliveira MR, Oliveira MW, BeHr GA AND MoreIRA JC. 2009a. Vitamin A supplementation at clinical doses induces a dysfunction in the redox and bioenergetics states, but did change neither caspases activities nor TNF-alpha levels in the frontal cortex of adult Wistar rats. J Psychiatr Res 43: 754-762.

De Oliveira MR, Oliveira MW, DA Rocha RF AND MOREIRA JC. 2009d. Vitamin A supplementation at pharmacological doses induces nitrosative stress on the 
hypothalamus of adult Wistar rats. Chem Biol Interact 180: 407-413.

De Oliveira MR, OliVeira MW, LORENZI R, FAgUndes DA Rocha R AND FonsecA MoreIRA JC. 2009b. Shortterm vitamin A supplementation at therapeutic doses induces a pro-oxidative state in the hepatic environment and facilitates calcium-ion-induced oxidative stress in rat liver mitochondria independently from permeability transition pore formation: detrimental effects of vitamin A supplementation on rat liver redox and bioenergetic states homeostasis. Cell Biol Toxicol 25: 545-560.

De Oliveira Mr, Oliveira MW and Moreira JC. 2010. Pharmacological doses of vitamin A increase caspase-3 activity selectively in cerebral cortex. Fundam Clin Pharmacol 24: 445-450.

De Oliveira Mr, Silvestrin RB, Mello e Souza T and MOREIRA JC. 2007b. Oxidative stress in the hippocampus, anxiety-like behavior and decreased locomotory and exploratory activity of adult rats: effects of sub acute vitamin A supplementation at therapeutic doses. Neurotoxicology 28: 1191-1199.

De Oliveira Mr, Silvestrin RB, Mello e Souza T AND MoreIRA JC. 2008. Therapeutic vitamin A doses increase the levels of markers of oxidative insult in substantia nigra and decrease locomotory and exploratory activity in rats after acute and chronic supplementation. Neurochem Res 33: 378-383.

De Oliveira Mr, Soares Oliveira MW, Müller HofF ML, BeHr GA, DA Rocha RF AND Fonseca Moreira JC. 2009c. Evaluation of redox and bioenergetics states in the liver of vitamin A-treated rats. Eur J Pharmacol 610: 99-105.

DEANE R ET AL. 2003. RAGE mediates amyloid-beta peptide transport across the blood-brain barrier and accumulation in brain. Nat Med 9: 907-913.

EDMONDSON DE. 2014. Hydrogen peroxide produced by mitochondrial monoamine oxidase catalysis: biological implications. Curr Pharm Des 20: 155-160.

Fenaux P, Chomienne C And Degos L. 2001. Treatment of acute promyelocytic leukaemia. Best Pract Res Clin Haematol 14: 153-174.

FISKER AB ET AL. 2014. High-dose vitamin A with vaccination after 6 months of age: a randomized trial. Pediatrics 134 : e739-748.

Folli C, Calderone V, Ottonello S, Bolchi A, Zanotti G, STOPPINI M AND BERNI R. 2001. Identification, retinoid binding, and $\mathrm{x}$-ray analysis of a human retinol-binding protein. Proc Natl Acad Sci USA 98: 3710-3715.

Furr HC, Amedee-Manesme O, Clifford AJ, Bergen HR 3RD, Jones AD, ANDERSON DP AND Olson JA. 1989. Vitamin A concentrations in liver determined by isotope dilution assay with tetradeuterated vitamin A and by biopsy in generally healthy adult humans. Am J Clin Nutr 49: 713-716.

GELAIN DP AND MOREIRA JC. 2008. Evidence of increased reactive species formation by retinol, but not retinoic acid, in PC12 cells. Toxicol In Vitro 22: 553-558.

Giasson BI, Duda JE, Murray IV, Chen Q, Souza JM, HurTig HI, IsCHIROPOULOS H, TROJANOWSKI JQ AND LEE VM. 2000. Oxidative damage linked to neurodegeneration by selective alpha-synuclein nitration in synucleinopathy lesions. Science 290: 985-989.

GRAHAM DG. 1978. Oxidative pathways for catecholamines in the genesis of neuromelanin and cytotoxic quinones. Mol Pharmacol 14: 633-643.

Green DR, GAlluzzi L AND Kroemer G. 2014. Cell biology. Metabolic control of cell death. Science 345(6203): 1250256.

HALLIWELL B. 2006. Oxidative stress and neurodegeneration: where are we now? J Neurochem 97: 1634-1658.

Hou N, Ren L, Gong M, Bi Y, Gu Y, Dong Z, LIU Y, CHEN J AND LI T. 2015. Vitamin A Deficiency Impairs Spatial Learning and Memory: The Mechanism of Abnormal CBPDependent Histone Acetylation Regulated by Retinoic Acid Receptor Alpha. Mol Neurobiol 51: 633-647.

HuANG P, ChANDRA V AND RAstineJAD F. 2014. Retinoic acid actions through mammalian nuclear receptors. Chem Rev 114: 233-254.

Hüttemann M, Pecina P, Rainbolt M, Sanderson TH, Kagan VE, SAMAVATI L, DOAN JW AND LEE I. 2011. The multiple functions of cytochrome $\mathrm{c}$ and their regulation in life and death decisions of the mammalian cell: From respiration to apoptosis. Mitochondrion 11: 369-381.

JiANG W ET AL. 2012. Vitamin A deficiency impairs postnatal cognitive function via inhibition of neuronal calcium excitability in hippocampus. J Neurochem 121: 932-943.

Jorg M, ScAmmells PJ AND CAPUANO B. 2014. The dopamine D2 and adenosine A2A receptors: past, present and future trends for the treatment of Parkinson's disease. Curr Med Chem 21: 3188-3210.

KaWaguchi R, Yu J, Honda J, Hu J, Whitelegge J, Ping P, WIITA P, BOK D AND SUN H. 2007. A membrane receptor for retinol binding protein mediates cellular uptake of vitamin A. Science 315: 820-825.

Klamt F, Dal-Pizzol F, Gelain DP, Dalmolin RS, Birnfeld de Oliveira R, BAstiani M, Horn F AND FONSECA MOREIRA JC. 2008. Vitamin A treatment induces apoptosis through an oxidant-dependent activation of the mitochondrial pathway. Cell Biol Int 32: 100-106.

Klamt F, Roberto de Oliveira M AND Moreira JC. 2005. Retinol induces permeability transition and cytochrome $\mathrm{c}$ release from rat liver mitochondria. Biochim Biophys Acta 1726: 14-20.

KONO Y AND FRIDOVICH I. 1982. Superoxide radical inhibits catalase. J Biol Chem 257: 5751-5754. 
Lam HS, Chow CM, PoOn WT, Lai CK, Chan KC, YeunG WL, HUI J, CHAN AY AND NG PC. 2006. Risk of vitamin A toxicity from candy-like chewable vitamin supplements for children. Pediatrics 118: 820-824.

LANE MA AND BAILEY SJ. 2005. Role of retinoid signalling in the adult brain. Prog Neurobiol 75: 275-293.

LEBEL CP, Ischiropoulos H AND BONDY SC. 1992. Evaluation of the probe 2',7'-dichlorofluorescin as an indicator of reactive oxygen species formation and oxidative stress. Chem Res Toxicol 5: 227-231.

Lotharius J AND BRUndin P. 2002. Pathogenesis of Parkinson's disease: dopamine, vesicles and alphasynuclein. Nat Rev Neurosci 3: 932-942.

MACTIER H AND WEAVER LT. 2005. Vitamin A and preterm infants: what we know, what we don't know, and what we need to know. Arch Dis Child Fetal Neonatal Ed 90: F103-108.

Maker HS, Weiss C, Silides DJ AND Cohen G. 1981. Coupling of dopamine oxidation (monoamine oxidase activity) to glutathione oxidation via the generation of hydrogen peroxide in rat brain homogenates. J Neurochem 36: 589-593.

MAROSI K AND MATTSON MP. 2014. BDNF mediates adaptive brain and body responses to energetic challenges. Trends Endocrinol Metab 25: 89-98.

MAWson A. 2013. Mefloquine use, psychosis, and violence: a retinoid toxicity hypothesis. Med Sci Monit 19: 579-583.

MYhre AM, CARLSEN MH, BOHN SK, WOLd HL, LAAKE P AND BLOMHOFF R. 2003. Water-miscible, emulsified, and solid forms of retinol supplements are more toxic than oilbased preparations. Am J Clin Nutr 78: 1152-1159.

Nagl F, Schönhofer K, Seidler B, Mages J, Allescher HD, Schmid RM, Schneider G ANd SAur D. 2009. Retinoic acid-induced nNOS expression depends on a novel PI3K/Akt/DAX1 pathway in human TGW-nu-I neuroblastoma cells. Am J Physiol Cell Physiol 297: C1146-C1156.

NAPOLI JL. 1996. Retinoic acid biosynthesis and metabolism. FASEB J 10: 993-1001.

NAPOLI JL. 1999. Retinoic acid: its biosynthesis and metabolism. Prog Nucleic Acid Res Mol Biol 63: 139-188.

NAPOLI JL. 2012. Physiological insights into all-trans-retinoic acid biosynthesis. Biochim Biophys Acta 1821: 152-167.

NAVigatore-Fonzo LS, Delgado SM, Golini RS AND ANzulovich AC. 2014. Circadian rhythms of locomotor activity and hippocampal clock genes expression are dampened in vitamin A-deficient rats. Nutr Res 34: 326-335.

Noy N. 2000. Retinoid-binding proteins: Mediators of retinoid action. Biochem J 348: 481-495.

O’Reilly KC, Shumake J, Gonzalez-Lima F, Lane MA AND BAILEY SJ. 2006. Chronic administration of 13-cis- retinoic acid increases depression-related behavior in mice. Neuropsychopharmacology 31: 1919-1927.

OLSON J. 1993. Vitamin A. Present Knowledge in Nutrition. The Nutrition Foundation, Washington, DC, p. 176-191.

PENNISTON KL AND TANUMIHARDJO SA. 2006. The acute and chronic toxic effects of vitamin A. Am J Clin Nutr 83: 191201.

Piskunov A, Al Tanoury Z and Rochette-Egly C. 2014. Nuclear and extra-nuclear effects of retinoid acid receptors: how they are interconnected. Subcell Biochem 70: 103-127.

RADI R. 2013. Peroxynitrite, a stealthy biological oxidant. J Biol Chem 288: 26464-26472

RESTAK RM. 1972. Pseudotumor cerebri, psychosis, and hypervitaminosis A. J Nerv Ment Dis 155: 72-75.

RochetTe-EGLY C. 2015. Retinoic acid signaling and mouse embryonic stem cell differentiation: Cross talk between genomic and non-genomic effects of RA. Biochim Biophys Acta 1851: 66-75.

RoDAHL K AND MOORE T. 1943. The vitamin A content and toxicity of bear and seal liver. Biochem J 37: 166-168.

Ross DA. 2002. Recommendations for vitamin A supplementation. J Nutr 131: 2902S-2906S.

SAKAI Y, CRANDALl JE, BRODSKY J AND MCCAFFERY P. 2004. 13-cis Retinoic acid (accutane) suppresses hippocampal cell survival in mice. Ann NY Acad Sci 1021: 436-440.

Sato T, Shimogaito N, Wu X, Kikuchi S, Yamagishi S AND TAKEUCHI M. 2006. Toxic advanced glycation end products (TAGE) theory in Alzheimer's disease. Am J Alzheimers Dis Other Demen 21: 197-208.

Sauvant P, Mekki N, Charbonnier M, Portugal H, LAIRON D AND BOREL P. 2003. Amounts and types of fatty acids in meals affect the pattern of retinoids secreted in human chylomicrons after a high-dose preformed vitamin A intake. Metabolism 52: 514-519.

SCHMIDT AM, YAN SD, YAN SF AND STERN DM. 2001. The multiligand receptor RAGE as a progression factor amplifying immune and inflammatory responses. J Clin Invest 108: 949-955.

Shearer KD, Fragoso YD, Clagett-Dame M AND MCCAFFERY PJ. 2012a. Astrocytes as a regulated source of retinoic acid for the brain. Glia 60: 1964-1976.

SHEARER KD, STONEY PN, MORGAN PJ AND MCCAFFERY PJ. 2012b. A vitamin for the braib. Trends Neurosci 35: 733-741.

Sheehan D, Meade G, Foley VM and Dowd CA. 2001. Structure, function and evolution of glutathione transferases: implications for classification of nonmammalian members of an ancient enzyme superfamily. Biochem J 360: 1-16.

SNODGRASS SR. 1992. Vitamin neurotoxicity. Mol Neurobiol 6: 41-73. 
Snyder H, Mensah K, Theisler C, Lee J, MatouscheK A AND WOLOZIN B. 2003. Aggregated and monomeric alphasynuclein bind to the S6' proteasomal protein and inhibit proteasomal function. J Biol Chem 278: 11753-11759.

SouZA JM, Giasson BI, CHEN Q, LeE VM AND Ischiropoulos H. 2000. Dityrosine cross-linking promotes formation of stable alpha-synuclein polymers. Implication of nitrative and oxidative stress in the pathogenesis of neurodegenerative synucleinopathies. J Biol Chem 275: 18344-18349.

SQUADRITO GL AND PRYOR WA. 1998. Oxidative chemistry of nitric oxide: the roles of superoxide, peroxynitrite, and carbon dioxide. Free Radic Biol Med 25: 392-403.

TAFTI M AND GHYSELINCK NB. 2007. Functional implication of the vitamin A signaling pathway in the brain. Arch Neurol 64: 1706-1711.

TAKeda A, NySSEn OP, Syed A, JANSEN E, BuEno-DeMesquita B And Gallo V. 2014. Vitamin A and carotenoids and the risk of Parkinson's disease: a systematic review and meta-analysis. Neuroepidemiology 42: $25-38$.
TANUMIHARDJO SA. 2004. Assessing vitamin A status: past, present and future. J Nutr 134: 290S-293S.

ThOMPSOn Haskell G, Maynard TM, ShatzMiller RA AND LAMANTIA AS. 2002. Retinoic acid signaling at sites of plasticity in the mature central nervous system. J Comp Neurol 452: 228-241.

TSunati H, Iwasaki H, Kawai Y, Tanaka T, Ueda T, UCHIDA M AND NAKAMURA T. 1990. Reduction of leukemia cell growth in a patient with acute promyelocytic leukemia treated by retinol palmitate. Leukemia Res 14: 595-600.

VAN LOO-BOUWman CA, NABER TH AND SchaAfsma G. 2014. A review of vitamin A equivalency of $\beta$-carotene in various food matrices for human consumption. Br J Nutr 111: 2153-2166.

VON LinTIG J. 2012. Provitamin A metabolism and functions in mammalian biology. Am J Clin Nutr 96: 1234S-1244S.

WANG H AND JOSEPH JA. 1999. Quantifying cellular oxidative stress by dichlorofluorescein assay using microplate reader. Free Radic Biol Med 27: 612-616. 